\title{
Macrothink
}

\section{Nurturing and Transferring Entrepreneurship in Thai Business Families}

\author{
Rungluck Naksung \\ School of Management, Shinawatra University \\ 197 Viphavadi-Rangsit Road, BBD Building (Viphavadi) \\ Samsen Nai, Phaya Thai, Bangkok 10400 Thailand \\ Opas Piansoongnern \\ School of Management, Shinawatra University \\ 197 Viphavadi-Rangsit Road, BBD Building (Viphavadi) \\ Samsen Nai, Phaya Thai, Bangkok 10400 Thailand \\ Email: opasplk@gmail.com
}

Received: February 9, 2018

Accepted: April 12, 2018 Published: May 30, 2018

doi:10.5296/jebi.v5i1.12833

URL: http://dx.doi.org/10.5296/jebi.v5i1.12833

\begin{abstract}
This research aims (1) to investigate patterns and phenomena of entrepreneurship formation in Thai business families; (2) to investigate practices of parent (the founders/predecessors of the business family) in nurturing and transferring entrepreneurship to their family members (successors); and (3) to build a model for nurturing and transferring entrepreneurship in Thai business families. The Semi-structured interview was used for collecting data from key informants who are potential successors of Thai business families. Eighteen potential family business successors participated in the interview. The study revealed that entrepreneurship in the Thai business families has been emerged since childhood developmental stages. The key practices of the Thai business families used for creating family entrepreneurship are: (1) Parental role modeling; (2) Parental family business practices; and (3) Parental support. However, the study disclosed and indicated that the founder or predecessor should build the family infrastructure before implementing any key practices. In this regard, the intellectual and mental factors were found as key elements. According to the findings, to be effective, these two factors must be created simultaneously.
\end{abstract}

Keywords: Family business, Business family, Nurturing entrepreneurship, Thailand 


\section{Rationale}

In the Asian business context, family enterprises play significant roles in both developed and developing countries. Thailand's family businesses, for example, are an important driver for the national economy wealth and growth since the country commenced its first economic development plan in 1961. In the meantime, Thai-Chinese family-owned businesses influenced and drove the economy under government concession. According to Forbes Magazine Thailand Edition (Forbes, 2017), 90\% of Thailand's businesspeople are members of the families doing businesses under concession in the past. These businesspeople have been controlling real estate, retail, food and beverages, agriculture, transportation, finance, and banking industries over 100 years. However, the important issue these families need to understand and implement is the effective ways of nurturing and transferring entrepreneurship from one generation to next generation successfully and sustainably. Since families are about caring and businesses are about benefits, the ultimate goal of business families is not just an ordinary formula for a successful partnership. Apart from satisfying employees, clients, partners, suppliers, and communities, family firms must deal with family issues which have direct and indirect effects on longevity and sustainability of the business (McMullen \& Warnick, 2015; Samei \& Feyzbakhsh, 2016). Because family firms must to balance the task of maximizing the full potential of the business while satisfying the expectations of the family members which can sometimes be challenging and critical to make decisions (Williams et. al., 2013).

In order to close the gap of family firms mentioned earlier, the family business research is brought to be one challenging agenda of social scientists around the world. Currently, there are a number of researchers pay much attention to investigate family business phenomena. The major topics are succession, branding, governance, culture, team building, leadership, and strategy. But the majority of empirical studies continues to be centered in the USA, Europe, and major economies in Asia such as China, Japan, and Singapore. There are few scientific researches about family entrepreneurship in Southeast Asia. The business families in Cambodia, Laos, Myanmar, Vietnam, and Thailand, are very interesting for both academics, economists, and entrepreneurs. A huge number of young working-class population with high purchasing power make these countries are considered as the new global market for all multinational corporations. In this regard, recognizing the business families' phenomena will enhance effectiveness of strategy planning, formulation and implementation. In a case of Thailand, there are few empirical studies focusing on the family business issue. Most research papers published in the national academic journals are mainly focused on family business succession and firm performance. There are not any investigations into the ways to nurture and transfer entrepreneurship within business families. Therefore, this research will beneficial for academics, business family founders, successors, and entrepreneurs in developing and strengthening their competitiveness within the family. Since their ownership, management, and family composition generate a complexity that requires special knowledge and skills in order to understand and advise them effectively. This empirical study aims to concentrate on processes (how families nurture and transfer entrepreneurship across generations) rather than contents or factors (what families do) better reflects the needs of 
different cultures, experiences and economic systems. Therefore, this research can be considered as the pioneer study about nurturing and transferring family entrepreneurship in Thailand.

\section{Literature Review}

\subsection{Concepts of Family Business}

A family business is the most common business form in the world's economies. It basically refers to a business which is formulated, owned, and managed by a family (Chua et al., 1999; Intihar \& Pollack, 2012). In a family firm, any business decisions are made by family members or a kinship group. These persons are substantial stakeholders involving in any issues of a family business such as ownership, management, governance, succession, investment, and employment (Intihar \& Pollak, 2012). According to the most cited study on a definition of the family business of Chua et al. (1999), a family business is usually governed and/or managed by members of the same family or a small number of families. The principal intention of the family is to shape and pursue the vision of the business for retaining and maximizing sustainable wealth across generations of the family or families.

\subsection{Nurturing Entrepreneurship across Generations}

Entrepreneurship is a multidimensional phenomenon and an interdisciplinary field (Alvarez et. al., 2005) in which the concepts are ambiguous and no consensus has been made about comprehensive theory of entrepreneurship (Eyal \& Inbar, 2003). The main function of entrepreneurship is to perceive and exploit opportunities, to create innovations, to bear uncertainty (Schumpeter, 1934; Bygrave \& Hofer, 1991). Entrepreneurship is individual's processes of discovering, developing, and exploiting of opportunities (Shane, 2000). A word "opportunity" refers to entrepreneurial opportunities which are situations in which tangible and intangible products and services can be traded at greater than their cost of production (Hisrich, Peters, \& Shepherd, 2013). In order to exploit these entrepreneurial opportunities, entrepreneurial action is required through the creation of products, services, and processes to access into markets. Since entrepreneurs typically make decisions of their projects under risky and uncertain situations where the stakes are high, time pressures are immersed, and there is extensive emotional investment. In this regard, entrepreneurs must be innovative and optimistic. They need procedures to turn individuals into entrepreneurs, to prepare them with crucial skills, to facilitate them to catch opportunities, to inspire them to generate creative ideas and to enable them to transform these ideas into working realities with confidence and competences (Kobia \& Sikalieh, 2010; Jones \& Iredale, 2010). Entrepreneurship commences with potential entrepreneurs who may or may not essentially undertake this activity, but have the beliefs and abilities to do so (Kelley, Singer, \& Herrington, 2012). Some studies indicate that entrepreneurship can be taught and learned (Gardner, 2015). Like this, entrepreneurship can be defined as a combination of individual attributes, skills, and behavior. Entrepreneurial attributes comprise of self-confidence, self-belief, perseverance, action orientation, preference for learning by doing, decision making process and creativity. Fogel (2001) indicates that skills necessary for individuals to become successful entrepreneurs are technical, managerial and entrepreneurship. Gibb (2005) broadens the expected skill-set to 
include creative problem solving, persuading, negotiating, strategic thinking, and networking. Additionally, Frank (2007) identifies a mixture of traits, knowledge, and skills comprising of-first, awareness and knowledge of enterprise and entrepreneurship that supports entrepreneurial activities; second, creativity, imagination, and a mindset; third, necessary business skills such as writing up business plans, starting up a venture, and retaining key customers (Kirby \& Humayun, 2013). Freytag and Thurik (2007) highlight propensity to take risk and self-confidence.

According to Schumpeter (1934), those attributes, skills, and behaviors are very important for entrepreneurs. Since they are persons who must invent and create novel products, processes, and services, penetrate markets with confidence, adapt themselves in fast changing environments and technologies, develop and implement newly creative business activities that enhance sustainable profitability and competitive advantages. Entrepreneurship researchers have found that entrepreneurship assists firms adjust to change, compete, and gain competitiveness and competitive advantage (Covin \& Miles, 2006). In comparison with non-family firms, family firms are less innovative, invest and register fewer patents, and enter fewer markets (Block, 2012; Block et al., 2013; Gómez-Mejía et al., 2010). Furthermore, much family business research has found that family entrepreneurship and commitment of owner-managers and their family team members decline impulsively when controlling power and ownership are passed from the founding to later generations (Block et al., 2013; Cruz \& Nordqvist, 2012; Gómez-Mejía et al., 2007). Some empirical studies indicate that business ownership and control of families encourage risk-averse behaviors among members in later generations to create new products and services, and enter new markets (Chrisman et al., 2012; Gómez-Mejía et al., 2007).

However, some researchers argue that family firms are sources of innovation and job creation. They are quite entrepreneurial because owner-managers understand that their survival depends on their ability to create novel and innovative products and services as well as to revitalize current operations in order to enhance competitiveness and competitive advantage in both existing and new markets. Research on entrepreneurship differentiates between more and less entrepreneurial degree in family firms by genetic, role modeling, and generation factors (Nicolaou \& Shane, 2009; Laspita et al., 2012). Cruz and Nordqvist (2012) found that genetic and role modelling factors diminish by third generation. At the same time, generation also found to distinguish degree of entrepreneurship in business families. Some empirical studies indicate that founders' entrepreneurial orientation, which are preferences of risk-taking, business aggressiveness, innovativeness, and proactiveness, is lost and firms usually become less entrepreneurial, creative, and innovative, when founders transfer ownership and control to their successors and family members become involved (Block et al., 2013; Gómez-Mejía et al., 2010; Miller, Le Breton-Miller, \& Lester, 2011). Other factors affecting degree of entrepreneurship in family businesses include family leader's tenure, leader's growth orientation, organizational culture of family, family-members' sense of unity, family's financial and social capital.

As discussed above, research on entrepreneurship in family firms does not provide process and implications about how families nurture entrepreneurship across generation. It only 


\section{MInstitute Macrothink $_{\text {Int }}$}

identifies family and firm factors that are associated with entrepreneurship in order to distinguish between more and less entrepreneurship in family firms. For this reason, the researcher further investigates succession in family business because it is an important issue and widely interesting topic in the field of family entrepreneurship. Research on succession indicates that 30 percent of business families can pass and continue their prosperity and competitive advantage to the second generation, and only 15 percent can maintain and transfer to the third (Ibrahim et al., 2001; Le Breton-Miller et al., 2004). The key factors discouraging transition of family firms are poorly organized plan, late implementation, and conflict among family members (De Massis et al., 2008). Le Breton-Miller et al. (2004) suggests that to manage these difficulties family firms should create and provide a high-quality predecessor-successor relationship (Chirico \& Salvato, 2008), robust environments for motivating successors (Remery, Matser, \& Flören, 2014), sufficient entrepreneurial education and work practice for the heirs (Bae et. al., 2014), family coherence, and having family governance such as a board of directors (De Massis et al., 2008). In research on succession, family relationship plays crucial roles in a transition from one generation to another, because the identity and history of the families are shared through generations. This is rooted in stories providing a way for business families to distribute knowledge and to resume norms and traditions (Parada \& Viladás, 2010). The mutual memory of a business family is a result of passions and time shared in a social setting. Chirico and Salvato (2008) state that quality of family business relationship has a substantial influence on the effectiveness of knowledge transfer, and the dynamic adjustment of the families particularly from current generation to the next. An intersection of personal and professional interactions within a family and in a family business is identified as the difficulties to develop and maintain smooth family relationship (Eddleston, Kellermanns \& Zellweger, 2012). Conflicts among family members, sibling, and non-family managers might arise from this overlapping role. Furthermore, there is a likelihood of marital discord, sibling rivalry, and children's desire to differentiate themselves from their parents (Chirico \& Salvato, 2008). In a study of Haberman and Danes (2007) about power structures and interactions among father-daughter and father-son family business decision teams, the findings reveal that female heirs experience more difficulties than her male siblings in father-son decision structure. This supports that quality of family relationship can be enhanced by quality of communication between founder-predecessor and successors because it is a strong factor for knowledge transfer and success of succession (Szulanski, 2000). Daughters are identified to be better at communicating with their fathers since they tend to be more caring for the father and to be more capable to reduce conflict (Smythe \& Sardeshmukh, 2013). In addition, sibling conflict and the relationship with non-family managers, are indicated to have an effect on family relationship (Vera \& Dean, 2005). In this case, family business heirs are recommended to make greater efforts in work for gaining trust from family members and non-family workers. However, research on succession mainly concentrates on the question of how a family successor is actually recruited and selected, but not how to nurture and endure entrepreneurship across generations.

Imprinting theory is another concept using to study entrepreneurship in family firms (Marquis \& Tilcsik, 2013). This theory states that important vision, strategy, knowledge, and skills that 
were introduced by the founder or forced by external conditions can become engraved on organizations, which is called "secondhand imprinting". These imprinted features can endure beyond the tenure of those who worked directly with the founder (Marquis \& Tilcsik, 2013). This theory envisages that individual and organizational responses to environmental conditions can persist long after environments have changed. At the individual level, the founders' features - values, vision, and behaviors - are regularly imprinted on the first day and can endure beyond the founders' exit (Geroski, Mata, \& Portugal, 2010) because macroeconomic circumstances experienced early in life have profound impacts on investors' risk propensity several decades later. Schoar and Zuo (2011) also support that executives who commenced their careers during a recession decide more conservative than others. At the organizational level, any actions or movements that leaders take and routinely develop during periods of environmental changes and stress lead to profound distinctions in strategies, structures, systems, styles of product and service offerings that become imprinted in that they persist over time (Marquis \& Tilcsik, 2013) such as organizational strategies, hiring criteria, and the founders' actions taken to cope with specific competitive circumstances (Geroski et al., 2010). According to the imprinting theory, this implies that actions, features, and conditions family founders or owner-managers take in earlier generations might become imprinted on family firms and also endure beyond generations at least as long as those who directly work with the founders and founding conditions live and have power on the family firms.

To conclude, there are several family factors such as genetic, role modeling, generation, founder's actions, that impact on entrepreneurship. Furthermore, after reviewing research on entrepreneurship, succession in family firms, and the imprinting theory, research on entrepreneurship describes reasons why family firms are more entrepreneurial than others, but not explain how to nurture entrepreneurship across generations. Similar to succession studies which mainly focus on process and factors that facilitate ordinary succession, but do not describe how entrepreneurship to be nurtured across generations. Whereas, the imprinting theory indicates that the secondhand imprinting can transcend generations, but does not yet to describe in what way. However, no theory to date describes how business families nurture entrepreneurship across generations, but there is a consensus to define this action as "trans-generational entrepreneurship" (Jaskiewicz et. al., 2015; Suess-Reyes, 2017).

\subsection{Research on Family business and Trans-generational Entrepreneurship in the Thai Context}

In Thailand, research on family business is most focused on succession, governance, and performance of the family businesses. Suehiro and Wailerdsak (2004) examined data both from firms listed in the Stock Exchange of Thailand and a survey of 220 local family businesses listed in 1997. The findings indicated that Thai family businesses can be categorized into four groups - closed family businesses, specialized family businesses, authoritarian family conglomerates, and modern family conglomerates. After the 1997 economic crisis in Southeast Asia, the falling trade barriers and the increasing globalization. Particularly the pressure of information and communication technology (ICT) are the key factors that force these business families to change their management of ownership and 
governance in the family businesses. In Thailand, the family businesses are mostly owned by Chinese families which have been the most powerful and dynamic form. These families can be considered as the important engine of the economic and industrial development of the country Wailerdsak (2012). However, the crucial factors influencing Thai family business survival and prosperity are the abilities of fund raising, new production adopting, and human resources managing and developing. Bertrand et. al. (2008) indicated that family size and family involvement in the ownership and control of the family businesses have an impact on performance and governance. Once the founders are dead, the elder sons and daughters often play a crucial role in both business ownership and board membership. In this case, a study found that sons' greater involvement can lower family firm performance (Bertrand et. al., 2008). However, a survey of the family firms and non-family firms in the Stock Exchange of Thailand during 2009 - 2014 revealed that performance of the family businesses is higher than the non-family ones (Apisakkul, 2015). It further found that family firms managed by family-member Chief Executive Officer (CEO) demonstrate higher gross profit margin, net profit margin, and return of asset than those managed by nonfamily-member CEO (Apisakkul, 2016a). While, corporate governance does not have an impact on financial performance of any family businesses listed in Thailand's Stock Exchange during 2008 - 2015 (Apisakkul, 2016b). In a study of 254 family business owners in Bangkok by Duangekanong and Duangekanong (2017), the study indicates that owner age, firm size and organizational formality have an impact on the comprehensiveness of the succession planning process, while, the comprehensiveness of the succession planning process had an influence on perceived success of the succession planning process.

In conclusion, most empirical studies on Thai family business have paid much attention on three dimensions - management, succession, and performance. Research on transgenerational entrepreneurship has not been mentioned. Thus, this research is beneficial to scholars and family business strategists in Thailand.

\section{Methodology}

Qualitative research is deemed the most appropriate for this study since the research questions are targeted to investigate on "how" and "why" questions which are: (1) When and how entrepreneurship is formed in business families?; and (2) How family members' entrepreneurship is nurtured and transformed by their parents (the founders/predecessors of the business)? What strategies do they use?

The Semi-structured interview was used for collecting data from key informants who are potential successors of Thai business families. The in-depth interview allows the researcher to explore, assess, and evaluate concepts, practices, and family strategies of trans-generational entrepreneurship in their natural setting. The interview questions cover the background of the firm and the interviewees, but the rest of the interview was focused on the interviewee's experience in the family business and the interviewee relationship with his or her father and mother (the founders/predecessors of the business). The interview questions are divided into two categories which are factual and developmental. The factual questions cover history and the size of the family and firm, employees, and general information 


\section{Macrothink}

regarding core family members and situations. The developmental questions cover information such as reasons of joining the family businesses, parents (the founders/predecessors of the business)-family members (potential successors) relationship, relationship among family members within their own family and with family of their relatives, and challenges faced by family members (potential successors) in multi stages of joining the family businesses.

Snowball and convenience sampling methods were used to recruit interviewees because family business potential successors and members are most reluctant to discuss family business issues with an outsider for fear of giving away business information to strangers. In this regard, the researchers approached potential successors from our personal network in one entrepreneurial training where potential successors attend for 10 weeks. The researcher contacted potential successors the researcher knows before asking if he or she could explore his or her network and identify as many potential interviewees as possible for this study. Each interview took place at the interviewees' offices or any convenient places and lasted between 45 to 60 minutes.

Table 1. Demographic Data of the Interviewees

\begin{tabular}{|c|c|c|c|c|c|c|c|c|c|c|}
\hline Case & Gen & Sex & Age & Status & Education & $\begin{array}{l}\text { Working } \\
\text { Year in } \\
\text { the } \\
\text { Family } \\
\text { Business }\end{array}$ & $\begin{array}{l}\text { \# of } \\
\text { Member } \\
\text { in the } \\
\text { Family }\end{array}$ & $\begin{array}{l}\text { Rank } \\
\text { in the } \\
\text { Family }\end{array}$ & $\begin{array}{ll}\text { Type } & \text { of } \\
\text { Business } & \end{array}$ & $\begin{array}{l}\text { Annual } \\
\text { Sales } \\
\text { (Million } \\
\text { THB)** }\end{array}$ \\
\hline 1 & 2 & $\mathrm{M}$ & 39 & Married & Master & 17 & 2 & 1 & Food* & $>1,000$ \\
\hline 2 & 2 & M & 32 & Married & Master & 7 & 2 & 1 & Trading & $>350$ \\
\hline 3 & 2 & M & 25 & Single & Master & 3 & 3 & 1 & Construction & $>1000$ \\
\hline 4 & 2 & M & 36 & Married & Bachelor & 5 & 3 & 1 & Beverage* & $>10,000$ \\
\hline 5 & 2 & M & 25 & Single & Master & 3 & 2 & 1 & Financial* & $>1,000$ \\
\hline 6 & 3 & M & 33 & Single & Bachelor & 3 & 2 & 1 & Food & $>300$ \\
\hline 7 & 3 & M & 27 & Single & Bachelor & 9 & 3 & 3 & Food & $>1,000$ \\
\hline 8 & 3 & $\mathrm{~F}$ & 46 & Single & Master & 10 & 4 & 2 & Trading & $>300$ \\
\hline 9 & 2 & $\mathrm{~F}$ & 41 & Single & Bachelor & 7 & 3 & 1 & $\begin{array}{l}\text { Home } \\
\text { Material }\end{array}$ & $>500$ \\
\hline 10 & 2 & $\mathrm{~F}$ & 38 & Married & Master & 6 & 3 & 3 & Media & $>300$ \\
\hline 11 & 2 & $\mathrm{~F}$ & 31 & Single & Master & 4 & 3 & 1 & Construction & $>300$ \\
\hline 12 & 2 & M & 33 & Single & Bachelor & 10 & 3 & 3 & Cosmetic* & $>1,000$ \\
\hline 13 & 3 & M & 46 & Married & Master & 15 & 3 & 1 & Food* & $>10,000$ \\
\hline 14 & 2 & $\mathrm{~F}$ & 35 & Single & Master & 6 & 4 & 3 & Trading & $>300$ \\
\hline 15 & 2 & $\mathrm{~F}$ & 22 & Single & Bachelor & 2 & 2 & 1 & Consulting & $>500$ \\
\hline 16 & 2 & M & 25 & Single & Master & 3 & 6 & 1 & Construction* & $>500$ \\
\hline 17 & 4 & $\mathrm{M}$ & 53 & Married & Bachelor & 32 & 3 & 1 & $\begin{array}{l}\text { Textile } \quad \& \\
\text { Hotel }\end{array}$ & $>1,000$ \\
\hline 18 & 2 & $\mathrm{~F}$ & 25 & Single & Bachelor & 4 & 3 & 3 & Construction & $>300$ \\
\hline
\end{tabular}

Remark: * means a listed company in the Stock Exchange of Thailand (SET)

* Exchange rate is 1 USD $=33$ Thai Baht

\section{Results and Discussion}

Based on the findings, two research questions which are: (1) When and how entrepreneurship is formed in business families? and (2) How family members' entrepreneurship is nurtured 
and transformed by their parents (the founders/predecessors of the business)? What strategies do they use? are answered. The study clearly demonstrates that entrepreneurship in the Thai business families has emerged since childhood developmental stages. Entrepreneurship of the potential successors should be built as soon as possible. The study found that the family infrastructure should be created before implementing further key practices. In this case, the infrastructure is divided into two parts. The first is the intellectual infrastructure. The family should provide sufficient education for being foundation to build on individual expertise. Intellectual also includes knowledge about life, society, and family. The study revealed that sufficient education is the key factor driving entrepreneurship in the families. The second is the mental infrastructure. The mentality is considered to be important because knowledge is not adequate. The potential successors must have positive mental status for understanding themselves and the others.

"My father doesn't hold any degree from the university. He's a hardworking man, but he loves reading. He always taught me and my brother and sister that education is the most valuable asset I can provide to you all. The financial assets can be taken by the others, but no one can take the wisdom from you. My father offers the educational freedom to us. For me, I love playing video game. I would like to be a game engineer when I was a boy. Therefore, my educational path is to study the computer engineering. Although, it's not related to my family business. My father still supports all the ways.” (Case 4, M, 36)

"Honestly, I'm pessimistic. As I told you, I have the freedom, but also have pressure from the others such as father's friends, suppliers, and customers. Before I work full time in the family firm, I don't believe in myself because it's impossible to be successful as well as my parents. Their working standard and quality are very high. Thus, I have to spend some years to gain trust on myself. In the past, my parents assigned me to do some small projects. Small win drives my passion." (Case 2, M, 32)

Once the family infrastructure is secured. Family predecessors should nurture entrepreneurship in their potential successor by implementing these practices.

(1) Driving passion on the family business. The passion on the family business is deemed the first key practice for nurturing and transferring entrepreneurship. Passion is comparable to the glue bonding the potential successors with the business. It can be created and enhanced through some participations such as an idea discussion conducting on the dinner table. While, some families drive passion by providing a small amount of fund to the potential successors. They are able to invest this amount in any businesses or financial alternatives. They are allowed to fail, but have to defend the reasons about what factors and why they fail.

"Trading is my passion as well as my father. I earned more than a million baht when I was studying the first year at the university. Although, I was a student at a premier university, but I did everything I could to earn money. It's fun and happy. Since then, my destination is to have my own business or expand my family business." (Case 12, M, 33) 
"When I was a boy, I looked at my father and thought that one day I must be great like him. He took me to almost everywhere he went. For example, I usually go with him to see our property or to greet and meet the clients and suppliers." (Case 1, M, 39)

"I am good at analyzing business and economic movements as well as my father. He usually asked me to watch TV news with him when I was a boy. At that time, I didn't understand what the news talk about but my father guided or hinted to me about the situations. It's wonderful. Nowadays, I always apply his analytical practices with my business decision making." (Case 5, M, 25)

(2) Providing sufficient information about the career path in the family business. The study revealed that a number of business families clearly inform and discuss about the career path, career growth and limitations with the family members. The potential successors must be free to choose their own destiny. The families which do not provide this information are likely to fail in nurturing and transferring entrepreneurship. The potential successors who are not able to see their future career path are likely to abandon the family businesses.

"I have realized my own destiny since I was a girl. I must work in the family business because the family needs me and I also need the family. When I saw and listen to my grandmother about the business and history of our family, I felt strong and would like to go on. Therefore, I will never think to be employed by any firms. In my opinion, the business heirs should commence to work for the family business as soon as possible. They need time to learn and to innovate the business." (Case 18, F, 25)

"Doing business is my passion. I have been doing business from when I was a boy. My grandfather is my idol. He is intelligent, creative, and visionary. He told me that "friendship and honesty are very important if you would like to succeed in any businesses. You must create both social and business networks yourself." I keep this advice in mind and exercise them continuously. Building the successful social and business networks needs a number of efforts and contributions. Social and emotional skills will be used and developed through various situations." (Case 7, M, 27)

(3) Practicing the work life balance activities. In this study, family activities are very important in the nurturing and transferring process. The families must manage and balance the work and life. The quality of family business relationship has a great influence on the effectiveness of knowledge transfer, and the dynamic adjustment of the families particularly from current generation to the next. Family activity is an effective strategy to encourage mutual memory of the family that will have an impact on passions, involvement, the success of nurturing and transferring entrepreneurship or transgenerational entrepreneurship (Gómez-Mejía et al., 2007, 2011) in the Thai business families.

"On Sunday, we usually stay at home and always dinner together [Laugh]. My father and two younger brother and sister always talk and share their business ideas and experiences because they work in the family business. I, as the eldest son, have to keep silent because I don't have any ideas. At that time, I felt I was an outsider and not belong to the family anymore. Until one day, I knocked the door of father's working room and told him that I would like to join 
the family. My father looked and smiled at me [Smile], and then he assigned me to work with his team. I have to learn a lot, but it's not difficult because the engineering is the good foundation for moving forward in the logistic and supply chain management fields." (Case 4, M, 36)

"In the past, I didn't understand my father about the way he works and manages his subordinates. I have to say to you that I and my father were not thick some years ago. I don't know how to explain this feeling. It looks like there is something in between us. I always go and talk with my mother first if I have to speak something to someone. However, I'm now understand his reasons and this changes my attitude toward my father. I have to say he is the great father, a man who works very hard for his family. He spends less money a day, but he pays a lot for the children. Now, it's my turn to take care of the family and the business. I and my parents, particularly my father, talk together almost every day. Last year, I had a brain surgery. That critical situation told me that money is not what my father desires. He can pay all his money in exchange of my health. Therefore, I will try my best to take care and protect my family and business as well as my father does for the whole life." (Case 16, M, 25)

However, the study found that parental role modeling, parental family business practices, and parental support, are the key driving forces in nurturing and transferring process. The parents or founders or predecessors of the family business should be good role models for the potential successor. Their characteristics lead to the process called "predecessor-successor identity alignment" (McMullen \& Warnick, 2015). This is a situation when the potential successors recognize that their own personality align with the parents or founders or predecessors of the family business. They will be simply inspired and the entrepreneurship will also be formed and developed. Life practices are another factor that influences the success of the formation of family entrepreneurship. This means the parents or founders or predecessors of the family business should create entrepreneurship through family activities such as family dinner, family TV time, and reading together. The activities will drive passion of the potential successors about the business. Furthermore, the parents or founders or predecessors of the family business should quietly introduce the business through some activities that take the potential successors to get involve in the business. Sharing of business ideas and experiences is a good strategy to inject entrepreneurship. Sharing is not only to distribute data and information about the business. It is also a way to accelerate creative ideas about the family and the business. However, the supports from the parents or founders or predecessors are very important. The parents or founders or predecessors of the family business should balance between their expectation and the demand of the potential successors. In some cases, when the potential successors are not interested in the family business. The parents or founders or predecessors of the family business should discuss and open the room for the potential successors to share and defend their ideas. These practices will enhance self-efficacy and locus of control of the potential successors.

In conclusion there is a model of transgenerational entrepreneurship in the Thai business families emerged from the study. This model is formulated from the results in the Thai context about the family businesses and the business families. The model proposes and 
suggests the effective process of nurturing and transferring entrepreneurship in the Thai business families as follows.

First, the founder or predecessor should build the family infrastructure which comprises of two main factors, intellectual and mental. The potential successors must be provided sufficient education. It is the foundation for creating and innovating their life, family, and business. While, the mentality is also identified as the key factor that the founder or predecessor should maintain. It is about emotional and social intelligence of the potential successors. According to the findings, these two factors must be created simultaneously.

"I didn't help my father and his team when I was studying in the high schools and university. He needs me to seriously focus on my education in order to develop my engineering expertise. However, I learned the family business when we have family dinner together. It always takes place on Sunday. My father always shares his working life, business ideas, and management techniques and techniques to me and my brothers. He never tells me to take care of the business, but I know I have to do it." (Case 3, M, 25)

Second, the family accelerators must be built and employed to enhance effectiveness of the nurturing and transferring process in the family. The accelerators are the parental role modeling, the parental family business practices, and the parental supports. The parental role modeling has a direct impact on the family factors which are predecessor-successor identity alignment, family involvement, family orientation, and family expectation. Once the potential successors are able to identify and to match their personality with the predecessors, they are likely to align themselves with the future career. In this case, if they are happy, they are like to work in the family business called "affective commitment" (McMullen \& Warnick, 2015). If they have no choice because they are the eldest son, eldest daughter or no one can replace their leading position, they are likely to work in the family business called "normative commitment" (McMullen \& Warnick, 2015). However, there are a number of potential successors who are happy to work in the family business because the cost of running their own venture is higher called "continuance commitment" (McMullen \& Warnick, 2015).

"I and my younger brother and sister were sent to work in Singapore together for about two years. This is a good practice and strategy of my father to train and to tight us. We understand the true meaning of family business and family from that moment. My father never tells us the expectation about business and family. He usually teaches us about the work philosophy." (Case 4, M, 36)

"My home and factory are located in the same area. It's simply to say that I grew up in the factory. Although, I didn't help my parents and relatives to work when I was a boy, but I'm familiar with this business. I knew the long history of our family business from my grandfather and father. Our family is Thailand's pioneer of tofu production and trade. There were a number of tofu production in the past, but economic and consumption changes decreased number of suppliers. Nowadays, I can claim that my family is the largest tofu producer in Thailand. In this regard, I try to create another brand to avoid any future risks. It doesn't mean only the business risk, but the family one, too. After I graduated from abroad, I immediately returned to Thailand and joined the family business as the eldest son. On the 


\section{Macrothink}

first day, I was new, but I try my best to learn and handle it. Although, I stayed in same area with the factory, but I didn't have a chance to learn about it. I just observed and learned by myself when I was a boy. If you ask me why I don't study the food technology in the undergraduate level, I would answer you that management is more complicated and running the family business is concrete management skills. This doesn't mean that I know nothing about food technology. I know the formula, production process and techniques, but it's my expertise." (Case 6, M, 33)

Third, the parental supports are very important to drive self-efficacy and locus of control of the potential successors. The founder or predecessor should support their children in the way they need. They should not be forced to take care of the family business. If the parent can do so, the effective process of nurturing and transferring entrepreneurship in the business families is likely to be successful.

"I spent almost 10 years in Melbourne, Australia [Smile]. Before that, my father asked me only one question "Would you like to go to Melbourne?" I read a newspaper and found that it's the world's most beautiful city. At that time, I just said "yes." A week later, he told me everything is ready for you. It's good to study over there. I have freedom to do whatever I want." (Case 13, M, 46).

"I never think to work in the family business because I'm a daughter. In a Chinese family, the father doesn't expect a daughter to succeed his business. I worked for few leading financial firms before joining the family business last ten years. Working with others is challenging, but organizational politics are trouble. When the organizational structure is adjusted, I moved back to the family. At that time, my father had some problems with my younger brother, but he is the first son of the family. I have to handle the business as well as to cooperate and compromise the two sides. As I'm never involved with the family business before, I have to spend a lot of time to manage myself. The father is a good coach, but he is a scolder. I have to manage and control my emotion before asking him for a question. As I used to work for leading financial firms before, I work hard for the family. I try to teach and coach my two younger brothers, but it's unsuccessful. Probably, I'm a woman.” (Case 8, F, 46)

"I love doing business. I exactly know that I'm not able to work under the supervision of the others when I was an intern at Thailand's leading petroleum firm. My grandmother is my inspiration. She told the story of our family business to me I was young. It's a miracle of a small family running a local convenient store to become a powerful family business in the Northeastern of Thailand. We were poor, but were highly honest. We focus on quality of our products and services. I usually helped my parents to work in the warehouse and the store before I was sent to attend a school in Singapore. I came back when I was about 18 years old. That time, I decided to study engineering, but my mother suggested me to change. I finally chose to study business English communication because I love the business. Once I graduated, I returned home and began to work with the family immediately. All are totally new. It's about engineering, but I can manage it because everyone is my books. Business is my passion. It begins within the family." (Case 18, F, 25) 


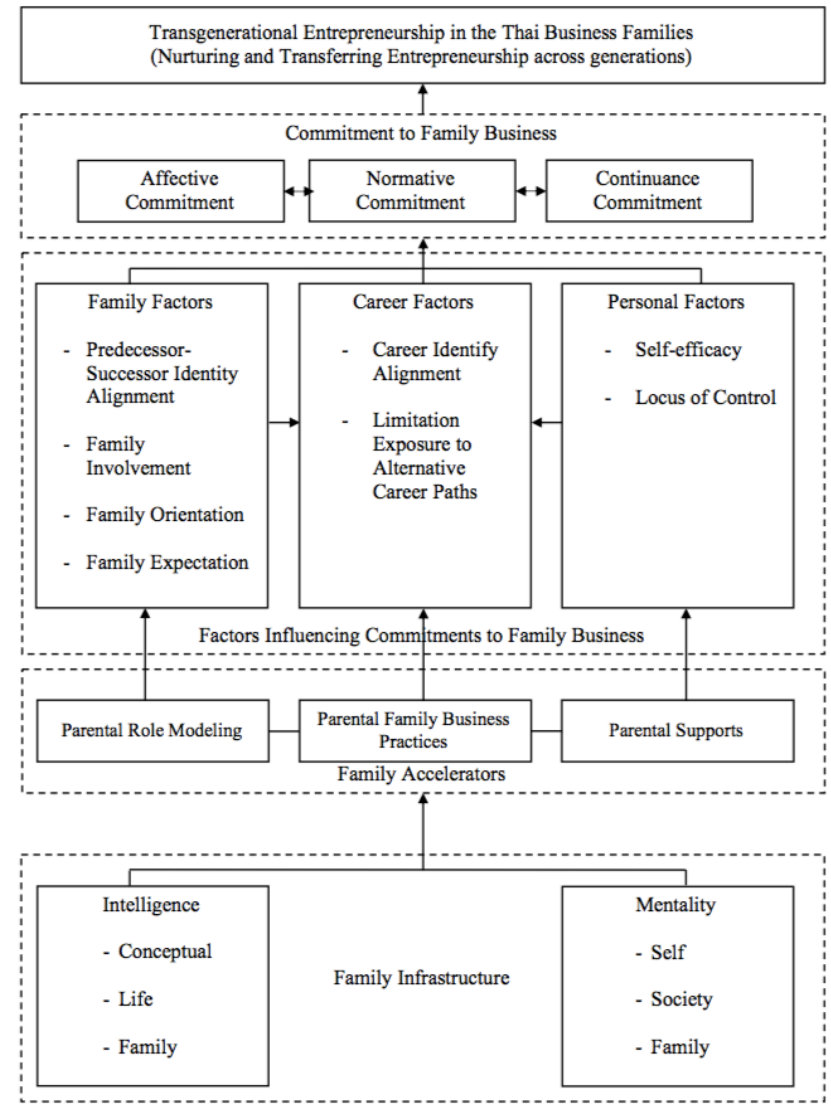

Figure 1. Model of Trans-generational Entrepreneurship in the Thai Business Families emerged from the study

\section{Implication for Business Families}

In order to nurture and transfer entrepreneurship across generations, business families should firstly provide sufficient education to potential successors because conceptual knowledge on any discipline is necessary for future career. Besides, if founders or predecessors need to gain affective commitment, they should not force potential successors to work or lead family businesses. In this regard, close relationship between founders or predecessors and potential successors should be developed since childhood because close relationship leads to love and understanding of family members. These two factors are important elements bonding everyone together.

Second, learning by doing approach is recommended as an important technique to educate potential successors. It is an important factor in a transformation of normative and continuance commitment to become affective commitment. The findings indicate that potential successors are pleased with working conditions that they are familiar with.

Last, founders or predecessors should provide work and social supports to potential successors for enhancing their self-efficacy and locus of control. Founders or predecessors are recommended to act as a coach who will support potential successors until they can run family businesses themselves. These two factors, self-efficacy and locus of control, lead to a creation of affective commitment and success of nurturing and transferring entrepreneurship 
in business families.

\section{Research Limitations}

In caring out this study, the researcher accepts that there are few limitations occurred. First, there are not many business families who would like to participate in the academic investigations because they are not sure about the confidentiality.

Second, the researcher was not allowed to observe the interviewees in the real workplaces and was not allowed to approach the parents.

Third, some sensitive issues, such as family conflict, are not revealed. In this case, personal relationship with the interviewees is very important.

Last, the in-depth interview period each time is limited by the tight schedule of the interviewees. Most of them have less time for the interview because they have to concentrate on their businesses before and after the office hours.

\section{Recommendations for Future Research}

There are several recommendations found from this investigation as follows:

First, quantitative research is recommended to examine and confirm the findings found from this qualitative study. Some factors that influence the trans-generational entrepreneurship process should be quantitatively investigated such as predecessor's characteristics. As the nature of quantitative research, a number of samples could use to effectively confirm the findings and expand some perspectives of the family businesses in Thailand.

Second, a comparison of Thai and international family businesses is recommended to investigate. The different practices of Thai and foreign families are very important factors in developing an effective trans-generational entrepreneurship framework for the business families in the Thai context. Both Thai and foreign family firms should have different practices, experiences, and solutions in nurturing and transferring entrepreneurship. Their diverse practices will expand the perspectives of trans-generational entrepreneurship in the Thai business context because the researcher believes that in a specific context like Thailand, a unique trans-generational entrepreneurship practice is needed.

Last, a comparative investigation of female and male successors should be conducted in order to investigate the factors that influence the success level of transgenerational entrepreneurship from different genders. Because in the same business context, female and male successors may have different career paths.

\section{References}

Alvarez, S. A., Agarwal, R., \& Sorenson, O. (2005). Handbook of entrepreneurship research: Interdisciplinary perspectives. New York: Springer.

Apisakkul, A. (2015). A Comparison of family and non-family business growth in the Stock Exchange of Thailand. UTCC International Journal of Business and Economics, 1, 63-74. 
Apisakkul, A. (2016). Family-owned management and firm performance: Evidence from public company in Thailand. UTCC International Journal of Business and Economics, 1, 61-71.

Apisakkul, A. (2016). A Comparison of family and non-family business growth in the Stock Exchange of Thailand. UTCC International Journal of Business and Economics, 2, 131-145.

Bae, T. J., Qian, S., Miao, C., \& Fiet, J. O. (2014). The relationship between entrepreneurship education and entrepreneurial intentions: A meta-analytic review. Entrepreneurship Theory and Practice, 31(3), 217-254. http://dx.doi.org/10.1016/j.ijme.2015.03.001

Bertrand, M., Johnson, S., Samphantharak, K., \& Schoar, A. (2008). Mixing family with business: A study of Thai business groups and the families behind them. Journal of Financial Economics 88, 466-498. http://doi.org/10.1007/s10490-014-9388-6

Block, J. H. (2012). R\&D investments in family and founder firms: an agency perspective. Journal of Business Venturing, 27, 248-265. http://dx.doi.org/10.1016/j.jbusvent.2014.07.001

Block, J. H., Miller, D., Jaskiewicz, P., \& Spiegel, F. (2013). Economic and technological importance of innovations in large family and founder firms: an analysis of patent data. Family Business Review, 26, 180-199. https://doi.org/10.1177/0894486513477454

Bygrave, W. D., \& Hofer, C.W. (1991). Theorizing about entrepreneurship. Entrepreneurship Theory and Practice, 16(2), 13-22. https://doi.org/10.1177/104225879201600203

Covin, J. G., \& Miles, M. P. (2006), Corporate entrepreneurship and the pursuit of competitive advantage. In: Zahra, S. (Ed.), Corporate Entrepreneurship and Growth. United Kingdom: Edward Elgar Publishing Ltd, 47-63.

Chirico, F., \& Salvato, C. (2008). Knowledge integration and dynamic organizational adaptation in family firms. Family Business Review, 21(2), 169-181. https://doi.org/10.1111/j.1741-6248.2008.00117.x

Chrisman, J. J., Chua, J. H., Pearson, A. W., \& Barnett, T. (2012). Family involvement, family influence, and family-centered non-economic goals in small firms. Entrepreneurship Theory and Practice, 36(2), 267-293. https://doi.org/10.1111/j.1540-6520.2010.00407.x

Chua, J. H., Chrisman, J. J., \& Sharma, P. (1999). Defining the family business by behavior. Entrepreneurship Theory and Practice, 23(4), 19-39. https://doi.org/10.1177/104225879902300402

Cruz, C., \& Nordqvist, M. (2012). Entrepreneurial orientation in family firms: A generational $\begin{array}{lllll}\text { perspective. Small } & \text { Business } & \text { Economics, } & 38,49 .\end{array}$ http://dx.doi.org/10.1016/j.jbusvent.2014.07.001

De Massis, A., Chua, J. H., \& Chrisman, J. J. (2008). Factors preventing intra-family succession. Family Business Review, 183-199. https://doi.org/10.1111/j.1741-6248.2008.00118.x

Duangekanong, D., \& Duangekanong, S. (2017). Succession Planning in Family Firms in 
Thailand: A Gender-Based Analysis. AU-GSB E-Journal, 10(1), 214-222.

Eddleston, K. A., Kellermanns, F. W., \& Zellweger, T. M. (2012). Entrepreneurial behavior of family firms: Does stewardship perspective explain the difference? Entrepreneurship Theory and Practice, 36, 347-367. https://doi.org/10.1111/j.1540-6520.2010.00402.x

Eyal, O., \& Inbar, D. E. (2003). Developing a public school entrepreneurship inventory: Theoretical conceptualization and empirical examination. International Journal of Entrepreneurial Behaviour \& Research, 9(6), 221-244. https://doi.org/10.1108/13552550310501356

Fogel, G. (2001) An analysis of entrepreneurial environment and enterprise development in Hungary. Journal of Small Business Management,39(1), 103-109. https://doi.org/10.1111/0447-2778.00010

Forbes Magazine Thailand Edition (2017). Thailand's 50 Richest. Retrieved from https://www.forbes.com/thailand-billionaires/list/\#tab:overall

Frank, A. I. (2007). Entrepreneurship and enterprise skills: A missing element of planning education. Planning Practice and Research, 22(4), 635-648. https://doi.org/10.1080/02697450701770142

Freytag, A., \& Thurik, R. (2007). Entrepreneurship and its determinants in a cross-country setting. Journal of Evolutionary Economics, 17(2), 117-131.

Gardner, D. (2015). Can entrepreneurship be taught? Northeast Pennsylvania Business Journal, 29(8), 24.

Geroski, P. A., Mata, J., \& Portugal, P. (2010). Founding conditions and the survival of new firms. Strategic Management Journal, 31, 510-529. https://doi.org/10.1002/smj.823

Gibb, A. (2005). The future of entrepreneurship education - determining the basis for coherent policy and practice?, in Kyrö, P. and Carrier, C. (Eds), The Dynamics Of Learning Entrepreneurship In A Cross-Cultural University Context, Entrepreneurship Education Series 2/2005, University of Tampere, Research Centre for Vocational and Professional Education, Hämeenlinna, 44-67.

Gómez-Mejía, L. R., Hynes, K. T., Núñez-Nickel, M., \& Moyano-Fuentes, H. (2007). Socioemotional wealth and business risk in family-controlled firms: Evidence from Spanish olive oil mills. Administrative Science Quarterly, 52(1), 106-137. https://doi.org/10.2189/asqu.52.1.106

Gómez-Mejía, L. R., Makri, M., \& Larraza-Kintana, M. L. (2010). Diversification decisions in family-controlled firms. Journal of Management Studies, 47, 223-252. https://doi.org/10.1111/j.1467-6486.2009.00889.x

Haberman, H., \& Danes, S. M. (2007). Father-daughter and father-son family business management transfer comparison: Family FIRO model application. Family Business Review, 20(2), 163-184. https://doi.org/10.1111/j.1741-6248.2007.00088.x 
Hisrich, R. D., Peters, M. P., \& Shepherd, D. A. (2013). Entrepreneurship. Singapore: McGraw-Hill.

Intihar, A., \& Pollack, J. M. (2012). Exploring small family-owned firms' competitive ability: Differentiation through trust, value-orientation, and market specialization. Journal of Family Business Management, 2(1), 76-86. https://doi.org/10.1108/20436231211216439

Ibrahim, A. B., Soufani, K., \& Lam, J. (2001). A study of succession in family firms. Family Business Review, 14, 245-258. https://doi.org/10.1111/j.1741-6248.2001.00245.x

Jaskiewicz, P., Combs, J. G., \& Rau, S. B. (2015). Entrepreneurial legacy: Toward a theory of how some family firms nurture transgenerational entrepreneurship. Journal of Business Venturing, 30, 29-49. https://doi.org/10.1016/j.jbusvent.2014.07.001

Jones, B., \& Iredale, N. (2010). Enterprise education as pedagogy. Education+Training, 52(1), 7-19. https://doi.org/10.1108/00400911011017654

Kelley, D. J., Singer, S., \& Herrington, M. (2012). The global entrepreneurship monitor 2011, $1-37$.

Kirby, D. A., \& Humayun, H. (2013). Outcomes of an entrepreneurship education programme: an empirical study in Egypt. International Journal of Management, 30(3/1), 23-35.

Kobia, M., \& Sikalieh, D. (2010). Towards a search for the meaning of entrepreneurship. Journal of European Industrial Training, 34(2), 110-127. https://doi.org/10.1108/03090591011023970

Laspita, S., Breugst, N., Heblich, S., \& Patzelt, H. (2012). Intergenerational transmission of entrepreneurial intentions. Journal of Business Venturing, 27, 414-435. https://doi.org/10.1016/j.jbusvent.2011.11.006

Le Breton-Miller, I., Miller, D., \& Steier, L. (2004). Toward an integrative model of effective FOB succession. Entrepreneurship Theory and Practice, 28, 305-328. https://doi.org/10.1111/j.1540-6520.2004.00047.x

Maccoby, E. E., \& Martin, J. A. (1983). Socialization in the context of the family: Parent-child interaction. In P. H. Mussen \& E. M. Hetherington (Ed.), Handbook of child psychology: Socialization, personality, and social development (4th ed., pp. 1-101). New York: Wiley.

Marquis, C., \& Tilcsik, A. (2013). Imprinting: toward a multilevel theory. Academy of Management Annals, 7, 195-245.

McMullen, J. S., \& Warnick, B. J. (2015). To nurture or groom? The parent-founder succession dilemma. Entrepreneurship Theory and Practice, 39(6), 1379-1412. https://doi.org/10.1111/etap.12178

Miller, D., Le Breton-Miller, I., \& Lester, R. H. (2011). Family and lone founder ownership and strategic behaviour: Social context, identity, and institutional logics. Journal of Management Studies, 48, 1-25. https://doi.org/10.1111/j.1467-6486.2009.00896.x 


\section{Macrothink}

Journal of Entrepreneurship and Business Innovation

ISSN 2332-8851

Nicolaou, N., \& Shane, S. (2009). Can genetic factors influence the likelihood of engaging in entrepreneurial activity? Journal of Business Venturing, 24, 1-22. https://doi.org/10.1016/j.jbusvent.2007.11.003

Parada, M. J., \& Viladás, H. (2010). Narratives: A powerful device for values transmission in family businesses. Journal of Organizational Change Management, 23(2), 166-172. https://doi.org/10.1108/09534811011031346

Samei, H., \& Feyzbakhsh, A. (2016). The effect of mentoring on successor nurturing in family businesses. The Journal of Entrepreneurship, 25(2), 211-231. https://doi.org/10.1177/0971355716650370

Schumpeter, J. A. (1934). The Theory of Economic Development. Cambridge, MA: Harvard University Press.

Shane, S., \& Venkataraman, S. (2000). The promise of entrepreneurship as a field of research. Academy of Management Review, 25(1), 217-226. https://doi.org/10.2307/259271

Smythe, J., \& Sardeshmukh, S. R. (2013). Fathers and daughters in family business. Small Enterprise Research, 20(2), 98-109. https://doi.org/10.5172/ser.2013.20.2.98

Suehiro, A., \& Wailerdsak, N. (2004). Family business in Thailand: Its management, governance and future challenges. ASEAN Economic Bulletin 21(1), 81-93.

Suehiro, A., \& Wailerdsak, N. (2014). Family business groups in Thailand: Coping with management critical points. Asia Pacific Journal of Management, 31, 997-1018. https://doi.org/10.1007/s10490-014-9388-6

Suess-Reyes, J. (2017). Understanding the transgenerational orientation of family businesses: the role of family governance and business family identity. Journal of Business Economics, 87, 749-777. https://doi.org/10.1007/s11573-016-0835-3

Szulanski, G. (2000). The process of knowledge transfer: A diachronic analysis of stickiness. Organizational Behavior and Human Decision Processes, 2(1), 9-27. https://doi.org/10.1006/obhd.2000.2884

Vera, C. F., \& Dean, M. A. (2005). An examination of the challenges daughters face in family business succession. Family Business Review, 18(4), 321-345. https://doi.org/10.1111/j.1741-6248.2005.00051.x

Wailerdsak, N. (2012). Succession of office in Thai family businesses. Journal of HR Intelligence, $7(2), 18-27$.

Williams, D. W., Zorn, M. L., Crook, T. R., \& Combs, J. G. (2013). Passing the torch: Factors influencing transgenerational intent in family firms. Family Relations, 62(3), 415-428. https://doi.org/10.1111/fare.12016 


\section{Macrothink}

\section{Copyright Disclaimer}

Copyright for this article is retained by the author (s), with first publication rights granted to the journal.

This is an open-access article distributed under the terms and conditions of the Creative Commons Attribution license (http://creativecommons.org/licenses/by/3.0/). 